This document is an electronic post-print of an article published in Slavic \& East European Information Resources: Giullian, Jon. "Reference Question Answered: Bibliographic Sources for the Ukrainian Periodical Press in the 1840's: Encyclopedias, Bibliographies, Guides, and Library Catalogs." Slavic \& East European Information Resources, 9.3 (2008): 278-284. http://dx.doi.org/10.1080/15228880802347723. Typographical errors have been corrected in this version. NOTE: Cites to this article should be made to the version published in SEEIR.

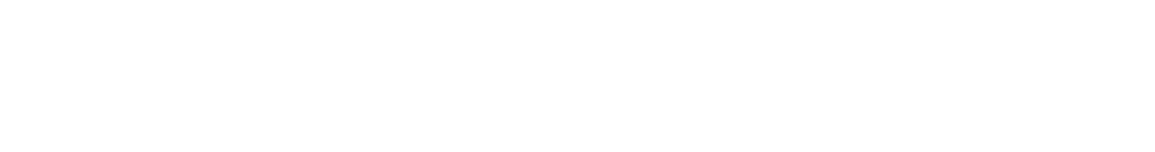

\section{Reference Question Answered: Bibliographic Sources for the Ukrainian Periodical Press in the 1840's: Encyclopedias, Bibliographies, Guides, and Library Catalogs}

Jon C. Giullian ${ }^{1}$

ABSTRACT. The author answers a reference question on the bibliographic sources for the Ukrainian periodical press from 1840-1850. Helpful publications include bibliographies, guides, and library catalogs that can be used to identify Ukrainian newspapers or journals of the period. These potentially make mention of revolutionary developments in Hungary (such as the " 12 Points" paragraph of the "Demands of the Hungarian Nation" in March 1848, the subsequent “April Laws," and Hungary’s declaration of independence in April 1949) and elsewhere in the Hapsburg Empire.

\footnotetext{
${ }^{1}$ Jon C. Giullian, MA, MLS, is Slavic Librarian, University of Kansas, 519 Watson Library, 1425 Jayhawk Blvd., Lawrence, KS 66045 (E-mail: giullian@ku.edu).
} 
KEYWORDS: April Laws, archives, Austria, bibliography, bibliographies, catalogs encyclopedias, guides, Hapsburg empire, Hungary, Hungarian, journals, Kiev, Kyiv, Lajos Kossuth, library, libraries, L'viv, newspapers, periodicals, press, Russia, Russian, Spring of Nations, Ukraine, Ukrainian.

Editor's note. This piece begins a new occasional feature of the "In Our Libraries" column, interesting and/or difficult reference questions and the sources used for answering them.

Question: "I am interested in the process by which news and rumor was conveyed during the tumultuous period of 1848. I have recently been reading Russian government documents about Peasant unrest during this year - in particular I have focused on the province of Kiev and surrounding lands. My question is this: are there any archives [or holdings] of Kievan newspapers and periodicals from this time? (1840's, but specifically 1848). I would like to see if any such sources that mention the events occurring in the Hapsburg empire, especially Hungary and the declaration of the April Thesis by Kossuth."

The first step in answering this question is to identify periodical titles published during the period in question (1840-1850). Danylo Husar Struk's History of Ukraine in five volumes provides a concise overview of the press for Western Ukraine and Russian-ruled Ukraine. See "Press" in volume 4 (p. 196-213). There were several newspapers published in Western Ukraine during the Revolution of 1848-1849. These included Gazeta Lwowska (1811-1918), Zoria halyts'ka (1848-1857), the pro-Polish Dnewnyk ruskij (1848), the Russophile Novyny (1849), Pchola (1849), and the Austrian government's Halycho-ruskii vistnyk (1849-1850). ${ }^{1}$ All were 
founded in L'viv.

In Russian-ruled Eastern Ukraine the first periodicals appeared in Kharkiv, the nucleus of academic and cultural life of the region, and were published in Russian. For the period in question, the semi-weekly paper Journal d' Odessa (1824-81), and the semi-weekly (from 1864 daily) Odesskii vestnik (1827-94) are listed. ${ }^{2}$ In Kiev the first “contract-fair paper to appear was Kievskie ob'iavleniia (1835-1838). From 1838 official Russian-language newspapers titled Gubernskie vedomosti were published weekly and later more often (e.g. daily in Karkhiv from 1874) in every gubernial capital.” 3 The Kievlianin (1840-1850), not to be confused with the tsarist paper Kievlianin (1864-1919), was the only other periodical to be published in Kiev. Just three issues were published (1840, 1841, and 1850). ${ }^{4}$ “The first Ukrainian newspaper - in spirit though not in language - the Kievskii telegraf (1859-1876), the unofficial organ of the Hromada of Kiev,” emerged much later. ${ }^{5}$

The absence of periodical literature published in Kiev has its roots in the political milieu of the period. Kiev was the administrative center of Ukraine under the Russian empire. In the spring of 1848 a series of nationalist movements and revolutions swept across most of continental Europe. Fueled by economic hardship in previous years (1846-1847), industrialization, and political resistance to liberal and nationalist reforms, uprisings began in France and quickly spread to Austria-Hungary, Italy, Switzerland, Germany, and into Eastern Europe. These movements became known as the "Spring of Nations."6

In Hungary, the revolutionary movement coalesced around Lajos Kossuth (1802-1894), a radical Hungarian nationalist whose program for reform was reflected in the famous "Twelve Points" paragraph of the "Demands of the Hungarian Nation."” While these reforms were enacted into law (known as the “April Laws”) more or less peacefully, armed conflict between 
Austria and Hungary ensued. Spurred on by Kossuth, Hungary’s National Assembly declared independence on April 14, 1849 and elected Kossuth to the post of state president-governor. Independence did not last long, however, as the Russian tsar Nicholas I, fearing the spread of revolution into the Russian Empire, sent troops to squash the Hungarian rebellion. ${ }^{8}$ Nicholas I's fears in 1848 were fed by events that took place in Ukraine in 1847, when a secret society called the Cyril and Methodius Brotherhood (Kyrylo-Metodiivs'ke bratstvo) had been exposed. Members, who included many prominent Ukrainian intellectuals, were arrested and punished without trial by Russian authorities. Perhaps in response to these events, censorship became even more severe under Nicholas I. In 1848 “a special committee was set up to watch the press in addition to the ordinary censors." ${ }^{9}$ Perhaps this explains why periodical literature published in Kiev, a potential revolutionary hotspot, was all but non-existent during the 1840’s.

The online guide of Ukrainian Periodical Bibliographies (UPB), produced by the Slavic and East European Library at the University of Illinois at Urbana-Champaign (UIUC), provides detailed annotations to bibliographies and catalogs on the Ukrainian periodical press for the $19^{\text {th }}$ and $20^{\text {th }}$ centuries. The following bibliographies should also prove useful in identifying periodical titles published in Kiev during the 1840’s.

Ihnatienko, V. Bibliografiia Ukrains’koi presy 1816-1916. Pennsylvania: State College, 1968. ["This is one of the most comprehensive bibliographies of Ukrainian periodical publications for the pre-revolutionary period. Titles are arranged chronologically. All publications focused on Ukraine are included here regardless of language. There are titles in Russian, German, and Polish. The entries are extensive for each title with complete publishing history, list of editors, and notes on title changes and changes in periodicity. The volume is also thoroughly indexed with a title index, an index of editors, index of place of publication and an index of publishers. This is an essential source for anyone doing research on the nineteenth century in Ukraine. It is also an important source for research on early Ukrainian émigré publications which can readily be identified here using the geographic index."10 According to Worldcat holdings data, the Toronto Public Library has the only copy of Ihnatienko's bibliography on this side of the Atlantic.]

Levytskii, I. E. Galitsko-russkaia bibliografiia XIX-go stoletiia s uvzgliadneniem russkikh 
izdanii poiavivshikhsia v Ugorshchine i Bukovine (1801-1886). Published 1888-1895. Reprinted in 1963 as Halyts'ko-ruskaia bybliohrafiia XIX-ho stolietiia. Vaduz : Kraus Reprint Ltd., 1963. ["Levytskii is important not only for identifying periodical titles. This source lists the contents of periodical publications." 10 It is widely available in North American academic research libraries.]

Romaniuk, M. M., Halushko, M. V. Ukrainski chasopysy L'vova 1848-1939. T. 1: 18481900. L'viv:Vydavnytstvo "Svit," 2001. ["This is a study of periodical publishing in Lvov during the turbulent years from 1848 to 1939. The first volume includes publications issued up to 1900. The entries here are very extensive. Each entry includes a history of the publication, citations to archival materials, and published works related to the journal. The citations are arranged chronologically into four sections: 1848-1859, $1860-1880,1880-1889$, and 1890-1900. The volume opens with a lengthy essay on the history of the press in the region, comprising the first 150 pages of the work. The bibliography also includes an index of names, an alphabetical list of titles, a chronological list of titles, and an alphabetical list of publishers. While this volume is limited to Lvov, it is an unusually thorough study of periodical publications in the 19th

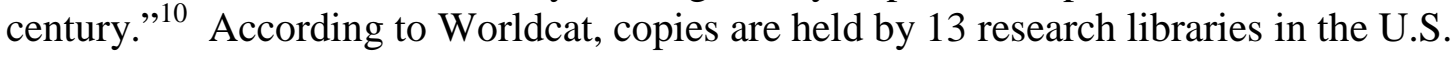
and Canada.]

Ukrains'ki periodychni vydannia. L'viv: Akademiia nauk Ukrains'koi RSR, 1990.

I chastina: 1816-1916 rr. u fondakh L'vivskoi naukovoi biblioteky im. V. Stefanyka AN URSR. Spisok. ["This is a list of the newspapers, journals, almanacs and other types of periodical publications issued in or about Ukraine between 1816 and 1916 and from 1917- 1945. The titles listed here reflect the holdings in the periodical archives of the Ukrainian Academy of Sciences. The entries are arranged alphabetically. Each entry includes very brief title and publication information along with a list of the library's holdings. The publication is, therefore, of particular interest to those planning research trips to Lvov.... There is a geographic index at the end of the volume which is essential for identifying these titles." 10 Worldcat shows copies held by the Library of Congress, New York Public Library, and the University of Illinois at Urbana-Champaign.]

Katalog dorevoliutsiynykh hazet, shcho vydavalysia v Ukraini (1822-1916). Publikatsiia fondu TSNB AN URSR. Kyiv: Akademiia Nauk URSR TSentral'na Naukova Biblioteka, 1971- ["This is a ...complete list of the newspaper holdings at the Ukrainian Academy of Sciences. All entries have complete publication information including the names of various editors involved with the papers. The exact holdings for each title are included with the alphabetically arranged entries. Titles published in the Latin alphabet are listed separately at the end of the volume. Most volumes include a geographic index of some sort. The first volume also includes an index of names facilitating access to the editors and publishers." 10 According to Worldcat, this title is held by many academic research libraries nationwide.]

Several other sources were consulted, including Murlin Croucher's Slavic Studies: A Guide to Bibliographies, Encyclopedias and Handbooks. Volume 2 or Croucher's work has a 
substantial section on Ukraine (p. 690-732). Entries 4332-4348 cover Ukrainian serials, including Ihnatienko’s Bibliography of the Ukrainian press (1816-1916), mentioned above. Patricia Grimstead's authoritative Archives of Russia: a directory and bibliographic guide to holdings in Moscow and St. Petersburg and Archives and manuscript repositories in the USSR: Ukraine and Moldova did not provide material relevant to the patron's research question.

Once identified, specific periodical titles can be searched in Worldcat in order to find holdings available in the U.S. and Canada. The holdings of major academic libraries in Ukraine, such as the Natsional'na biblioteka Ukrainy imeni V.I. Vernads'koho ${ }^{11}$ in Kiev and the L'vivs'ka naukova biblioteka im. V. Stefanyka NAN Ukraïny (LNB NAN) ${ }^{12}$ in L'viv, should also be consulted, as they are the most likely academic libraries to hold historical Ukrainian periodicals. During the period in question, the Hapsburgs had placed Galicia (capital: L’viv) under Polish autonomous home rule, and its citizens participated in the revolts of 1848 and submitted petitions to the emperor in Vienna; thus holdings in L'viv might be particularly useful. Other major academic libraries, including the Russian State Library (Moscow, Russia), ${ }^{13}$ the National Library of Russia (St. Petersburg, Russia), ${ }^{14}$ and the Jagiellonian Library ${ }^{15}$ in Cracow, Poland may also prove useful for individual titles.

\footnotetext{
${ }^{1}$ Kravtsiv B. and, R. Senkus. "Press.” in Encyclopedia of Ukraine, vol. 4, Ed. Danylo Husar Struk. Toronto: University of Toronto Press, Inc., 1984, 196-213. [See sub-heading Western Ukraine on p. 196].

${ }^{2}$ Kravtsiv B. and, R. Senkus. "Press.” in Encyclopedia of Ukraine, vol. 4, Ed. Danylo Husar Struk. Toronto: University of Toronto Press, Inc., 1984, 196-213. [See sub-heading Russian-ruled Ukraine on p. 197].

${ }^{3}$ Kravtsiv B. and, R. Senkus. "Press.” in Encyclopedia of Ukraine, vol. 4, Ed. Danylo Husar Struk. Toronto: University of Toronto Press, Inc., 1984, 196-213. [See sub-heading Russian-ruled Ukraine on p. 197].
} 
${ }^{4}$ Kravtsiv B. and, R. Senkus. “Kievlianin.” in Encyclopedia of Ukraine, vol. 2, Ed. Danylo Husar Struk. Toronto: University of Toronto Press, Inc., 1984, p. 221.

${ }^{5}$ Kravtsiv B. and, R. Senkus. “Press.” in Encyclopedia of Ukraine, vol. 4, Ed. Danylo Husar Struk. Toronto: University of Toronto Press, Inc., 1984, 196-213. [See sub-heading Russian-ruled Ukraine on p. 197].

${ }^{6}$ Stearns, Peter N., ed. The Encyclopedia of World History: Ancient, Medieval, and Modern, Chronologically arranged, $6^{\text {th }}$ ed. Boston: Houghton Mifflin Company, 2001, p. 465.

${ }^{7}$ Molnár, Miklós. A Concise History of Hungary. Cambridge, U.K.: Cambridge University Press, 2001, p. 185.

${ }^{8}$ Molnár, Miklós. A Concise History of Hungary. Cambridge, U.K.: Cambridge University Press, 2001, p. 192193, 197-198. [For more information on Hungarian history see: (a) Vardy, Steven Bela. Historical Dictionary of Hungary, Lanham, Md.: Scarecrow, 1997. (b) Kontler László. A History of Hungary: Millennium in Central Europe. New York: Palgrave Macmillan, 2002. (c) Lendvai, Paul. The Hungarians: A Thousand Years of Victory in Defeat, Ann Major, trans. Princeton, NJ: Princeton University Press, 2003. (d) Sugar, Peter F., Péter Hanák, and Tibor Frank, eds. A History of Hungary. Bloomington, IN: Indiana University Press, 1990.]

${ }^{9}$ The New Cambridge Modern History, v. 10: the Zenith of European Power 1830-1870. Cambridge: Cambridge University Press, 1960, p. 128.

${ }^{10}$ Ukrainian Periodical Bibliographies. Slavic and East European Library, University of Illinois at UrbanaChampaign <http://www.library.uiuc.edu/spx/class/Periodicals/Ukraine/ukraineper.htm>

${ }^{11}<$ http://www.nbuv.gov.ua>

${ }^{12}<$ http://www.huri.harvard.edu/abb_grimsted/L-3.html >

${ }^{13}<$ http://www.rsl.ru>

${ }^{14}<$ http://www.nlr.ru/eng $>$

${ }^{15}<$ http://www.bj.uj.edu.pl> 